\title{
Trends in the settlement of migrant workers in the context of social and economic processes in contemporary Russia
}

\author{
Mikhail Yuryevich Zelenkov ${ }^{1}$, Aleksander Aleksandrovich Nikolaev ${ }^{1}$, Pavel Viktorovich \\ Razov $^{1}$, Tatiana Innokentyevna Pak $^{1}$, and Julia Olegovna Sulyagina ${ }^{2}$ \\ ${ }^{1}$ Financial University under the Government of the Russian Federation, Department of Sociology, \\ Moscow, Russia \\ ${ }^{2}$ Russian State Social University, Department of Management and Administrative Management, \\ Moscow, Russia
}

\begin{abstract}
The purpose of the article is to identify the basic trends in the settlement of migrant workers in the Russian Federation. The methodology of the research was based on the humanistic approach, which allowed focusing on the problems of labor migrants' life activity and their search for value-based orientations. The systemic and comprehensive approach allowed identifying and substantiating the directions of the trends in the settlement of labor migrants by regions and districts of Russia. The comparative analysis of scientific works helped to identify the causes of settlement of labor migrants by place of their labor activity. Two identified opposing trends are the main results of the study. The first is dispersed settlement, which objectively promotes the integration process of representatives of immigrant ethnic groups into the urban environment of the area of residence, at the expense of a simultaneous weakening of intra-ethnic social ties and an increase in the depth and density of contacts with the local population. The second is the opposite trend - the self-isolation of immigrant groups within the framework of compact settlements, leading to the emergence of large ethnic diasporas of migrants in certain areas of the hosting country. The novelty of the study comes from an original approach to the identification and justification of migrants' settlement trends in the socio-economic conditions of modern Russia.
\end{abstract}

Keywords: tendency, adaptation, integration, migration, labor migrants

\section{Introduction}

International migration has become a global phenomenon in the second decade of the $21^{\text {st }}$ century. More and more people are looking for employment opportunities outside their countries. Before the global pandemic, according to the World Bank, the number of

\footnotetext{
* Corresponding author: mz60@mail.ru
} 
migrants (not including refugees) reached about 240 million, but even more impressive is the amount of remittances sent home by foreign workers - \$483 million [1]. In recent years, labor migration has tended to change in terms of settlement by regions and districts of the country of their stay. Moreover, the changing geography of labor migration was first noted in scientific papers in the United States in the 1990s [2, 3], followed by parallel developments concerning the southern parts of Europe at the turn of the millennium [4-6]. Studies on the settlement of labor migrants in the northern parts of Europe have recently emerged and contain the EU enlargement process that began in 2004 in their origins [7-10].

As for Russia, studies show that the increased pace of development of its economy, economic restructuring, together with a low inflow of replenishment of the national labor market due to the low birth rate among Russians and the increased duration of education for young people has resulted in relatively high demand for labor resources in the Russian Federation [11]. A comparative analysis of scientific works has revealed a wide range of methodological approaches to the study of labor migration: demographic [12], political science [13], historical [14], sociological [15-17], psychological [18, 19], economic [20]. The problem of labor migration is also considered on the basis of the network approach [21], the new institutional approach [22-24], risk theory [25], the concept of "human capital" [26-28].

Such a wide range of methodological approaches can be explained by the fact that the Russian population, for the most part, has a relatively high level of general education and professional qualifications, and mostly has the job that corresponds to its level of capabilities, needs, and interests. In addition, the domestic representatives of the working population avoid taking low-skilled, low-paid, and non-prestigious jobs, even despite the unemployment (5.8\% as of January 2021, according to Rosstat). All this combined has led to the fact that Russia has a shortage of low-skilled labor force, which started to be eliminated by immigration of labor force mainly from the CIS countries, where there is an excess of labor population, primarily Uzbekistan, Moldova, Tajikistan, and Kyrgyzstan. Under these conditions, the process of labor migration has become so important that it already affects the formation of certain sectors of the labor market in Russia (construction and utilities).

In such an environment, a dilemma for the executive branch is on the agenda. On the one hand, the Russian economy is experiencing an acute shortage of human resources, which is eliminated, to a large extent, with the help of foreign hired workers. On the other hand, for the successful use of such personnel, it is necessary to create conditions for their adaptation and safe labor activity. Adaptation should be understood as a process of adjustment of incoming workers to different living conditions. As a result, new behavioral stereotypes are formed, and a new way of life is actually developed, which implies a certain structure, including the main areas of people's life: financial, economic, social, family, religious, household, security. An important role in this process is played by the area and region of foreign workers' settlement, which today is already subject to certain unwritten laws. This study is devoted to identifying the main trends in the settlement of migrants in Russia.

\section{$2 \quad$ Materials and methods}

The methodological basis of the study consists of scientific works that describe the problem of labor migration $[1-12,15,17,21,26,27,29-34]$ and trends in the settlement of migration in different regions of the world and in Russia [13, 16, 23, 35-39]. The methodology of the study included a humanistic approach, which allowed focusing on the problems of migrant 
workers' life activity and their search for value-based orientations, a systemic and comprehensive approach, which allowed identifying and substantiating the trends in the settlement of migrant workers in the regions of Russia, and a comparative analysis of scientific works in order to determine the causes of migrant workers' settlement in the regions of their labor activity.

\section{$3 \quad$ Results}

The results of the study led to the following conclusions:

1. Labor exporting countries (Kyrgyzstan, Tajikistan, Uzbekistan, Ukraine, Moldova, Belarus) are interested in labor migration of their citizens to Russia because it reduces social tension in these countries and helps labor migrants to survive in conditions of low level of economy of those countries.

2. Generally the migration process in Russia has acquired a recurring character: some foreign workers return to their homes, others acquire the status of permanent residents. As a result, the internal structure of labor migrants begins to change.

3. The areas of employment of migrant workers are vegetable and clothing markets, construction sites, the service sector, and the housing and utilities sector, where locals do not want to work as long as they consider such work to be non-prestigious, unskilled, and low-paid.

4. The process of settlement of migrant workers in Russia is characterized by two opposite trends.

The first is dispersed settlement, which objectively contributes to the integration process of ethnic groups in the urban environment by simultaneously weakening intra-ethnic ties and increasing the depth and density of contacts with the local population. This trend is characteristic of rural and sparsely populated areas where labor migrants stay, since the process of living in this area requires the integration of residents, regardless of ethnicity and citizenship of the population.

The second trend is opposite. It is self-isolation of immigrant groups within compact settlements. Such settlements are formed along ethnic lines and are controlled by the respective ethnic diaspora. In these areas, migrants live in accordance with their ethnic culture, traditions, and customs of family and household life. For example, in Moscow, the best-known places for such localization of migrant workers are Ochakovo, Lianozovo, Tekstilshchiki, Koptevo, Lyublino, Biryulevo. It is extremely difficult to estimate the number of their inhabitants since many of them are illegal migrants who are not eager to have contact with the official authorities.

\section{Discussion}

Historically, international labor migration has been an urban phenomenon. Most immigrants settled in large cities and industrial regions, where the demand for labor is the highest [31]. This is since the central issue of the migration process is employment and earning financial resources. Some experts express the opinion that "guest workers" contribute to the increase of unemployment in the country because they take the jobs of Russians. However, as studies show, the incoming labor force, for the most part, does not compete in the Russian labor market with locals, because it occupies its own niche and performs such types of work that are not attractive to Russian citizens [36], especially in 
such large cities as Moscow and St. Petersburg, where fundamental investment projects of Russia are concentrated.

The main reason for this situation is that jobs with a predominance of unskilled and semi-skilled labor are not in demand in the Russian labor market due to low wages and labor content that does not meet the needs of the local population [38]. In addition, it has become obvious that foreign labor is needed even in situations of economic crisis and unemployment. It is no longer possible to replace migrant workers with locals in monotonous and tedious, dirty and hard, low-paid and non-prestigious jobs that do not require high qualifications [30].

At the same time, it should be noted that the complicated procedure for obtaining a work permit and strict registration rules lead to informal labor activity. Labor migrants, in conditions of legal uncertainty, tend to agree to work without guarantees from the employer. But this form of employment, in practice, often means low wages, no protection from being dismissed at any time, increased risk of injury at work, unregulated working hours, lack of collective agreement, trade union, vacations, any social benefits, etc.

In such a situation, guest workers try to get a job with their fellow countrymen, since they have some guaranteed minimum for accommodation and payment. Also, there is a new lower level being formed among foreign workers, which seems to be between two worlds. On the one hand, being in a foreign country, a migrant is largely alienated from his or her culture and, at the same time, remains for a long period excluded from the social life of the host country. Finding themselves in a different socio-cultural environment, guest workers begin to feel the difficulties associated with differences in customs and traditions, social attitudes, and value-based orientations in the process of interacting with the local population. At the same time, the social and cultural component of "guest workers" often forms misunderstanding and causes irritation among the locals [29].

This sometimes discriminatory and sometimes unfriendly attitude towards "guest workers" on the part of some local residents has a socio-psychological property [37], which prevails over the personal one - "I don't like the "newcomers", our electrician is a nice guy though". At the same time, the presence of discriminatory attitudes towards migrants is closely connected with the socio-economic situation in which the local population finds itself and reflects the uncertainty and unreliability of their positions in society, as well as the uncertainty about the future. Some Russians seek to compensate for this in the form of the superiority demonstration for their national group and thus consolidating their position.

Practice shows that not only migrant workers, but also their families with their natural needs begin to exist in the Russian social infrastructure, and the age and sex structure of ethnic diasporas become close to that of the local population [39]. This leads to a significant "visibility" of migrants in some cities. They begin to be competitors for some of the locals in the urban housing market and, as a result, the intracity structure changes. As a consequence, the tendency of national concentrations is formed, which leads to the emergence of a parallel social subsystem with its own specific needs, interests, and most importantly, requirements for the social medium of migrants' stay.

\section{Conclusion}

Thus, the study has shown that for the stable existence of the market in Russia, the executive power should timely identify the prevailing trend of the settlement of labor migrants in its region and implement a migration policy considering the identified trend. Competent formulation of migration policy, that reflects the prevailing trend of the settlement of migrant workers in a municipal or urban area will help to timely uncover the 
threats that contribute to the radicalization of migrant workers and encourage their behavior toward social society.

The authors note that this study is only one of the possible vector approaches to the problem of labor migration. One should not limit oneself to identifying the trends outlined, but should further substantiate the factors influencing this process. Given that the results of this study are based on macro-level scientific documents, it would be useful to study this issue at the micro-level as well. Such a study might allow for a better understanding of the subject matter under analysis.

\section{References}

1. Migration and Development Brief. Accessed on: October 18, 2021. [Online]. Available:https://www.knomad.org/publication/migration-and-development-brief-31

2. D.S. Massey, New Faces in New Places: the Changing Geography of American Immigration (Russell Sage Foundation, New York, 2008)

3. V. Zuniga, Hernandez-Leon R. New Destinations: Mexican Immigration in the United States (Russell Sage Foundation, New York, 2005)

4. K. Hoggart, C. Mendoza, Sociol Rural, 39(4), 538-562 (1999)

5. J. Gertel, S.R. Sippel, Seasonal Workers in Mediterranean Agriculture (Routledge, Abingdon, 2014)

6. A. Corrado, C. de Castro, D. Perrotta, Migration and Agriculture Mobility and Change in the Mediterranean (Area Routledge, London, 2017)

7. B. Jentsch, Int J Multicult Soc, 9, 1-12 (2007)

8. R. McAreavey, Sociol Rural, 52, 488-507 (2012)

9. S. Scott, P. Brindley, Geography, 97, 29-38 (2012)

10. S. Scott, Popul Space Place, 19(5), 459-471 (2013)

11. I. Polevoy, A. Shunyaev, Man Labor, 11, 55-61 (2012)

12. P.P. Lisitsyn, Sravnitelnyi analiz sotsialnoi adaptatsii legalnykh trudovykh migrantov iz Vyetnama i Uzbekistana v Sankt-Peterburge [Comparative analysis of the social adaptation of legal labor migrants from Vietnam and Uzbekistan in St. Petersburg], $\mathrm{PhD}$ thesis in Sociology (Moscow, 2009)

13. T. Regent, Econ Sci Mod Rus, 3, 96-107 (1998)

14. V.P. Budakov, Rossiya v poiskakh sebya [Russia in quest of itself] (ROSSPAN, Moscow, 2007)

15. L.M. Drobizheva, Sotsialnye problemy mezhnatsionalnykh otnoshenii v postsovetskoi Rossii [Social problems of interethnic relations in post-Soviet Russia] (Center for Universal Values, Moscow, 2003)

16. L.L. Rybakovsky, Migratsiya naseleniya (teoreticheskie voprosy) [Population migration (theoretical questions)] (ISPII RAN, Moscow, 2003)

17. V.V. Petrov, Etnicheskie migranty v prinimayushchem obshchestve. Metodologiya i teoriya issledovaniya tolerantnosti i migrantofobii [Ethnic migrants in the host society. Methodology and theory of research of tolerance and migrant-phobia] (Krasnodar, 2005)

18. V.N. Pavlenko, Psikhologicheskaya adaptatsiya i reabilitatsiya vynuzhdennykh migrantov: podkhody i problemy. Akkulturatsionnye strategii i modeli transformatsii 
identichnosti migrantov [Psychological adaptation and rehabilitation of forced migrants: approaches and problems. Accultural strategies and models of identity transformation in migrants], in G.U. Soldatova (ed), Psychology of refugees and forced migrants: the experience of research and practical work (Smysl, Moscow, 2001)

19. T.G. Stepanenko, Adaptatsiya k novoi kulturnoi srede [Adaptation to the new cultural environment], in Ethnopsychology (Aspect-Press, Moscow, 2003)

20. V.V. Radaev, J Sociol Soc Anthrop, IV(3), 109-130 (2001)

21. G.V. Gradoselskaya, Setevye izmereniya v sotsiologii [Network measurements in sociology] (Novyi Uchebnik, Moscow, 2004)

22. S.G. Kirdina, Sociol Res, 12, 23-33 (2002)

23. V.I. Mukomel, Migratsionnaya politika Rossii: postsovetskii kontekst [Migration policy of Russia: Post-Soviet context] (Dipol-T, Moscow, 2005)

24. J.M. Hodgson, Viability of institutional economics, in Evolutionary economics at the threshold of the XXI Century. Papers and speeches of the International Symposium, 29-74 Pushchino, September 23-25, 1996 (Japan Today, Moscow, 1997)

25. V.P. Buyanov, K.A. Kirsanov, D.M. Mikhailov, Riskologiya. Upravlenie Riskami [Riskology. Risk Management] (Ekzamen, Moscow, 2006)

26. G. Bekker, Povedenie cheloveka: ekonomicheskii podkhod [Human behavior: economical approach] (GU - Higher school of economics, Moscow, 2003)

27. R.I. Kapelyushnikov, Rossiiskii rynok truda: adaptatsiya bez restrukturizatsii [Russian labor market: adaptation without restructuring] (GU - Higher school of economics, Moscow, 2001)

28. Y.A. Korchagin, Chelovecheskii kapital kak intensivnyi sotsialno-ekonomicheskii faktor razvitiya lichnosti, ekonomiki, obshchestva i gosudarstvennosti [Human capital as an intensive socio-economic factor in the development of personality, economy, society, and statehood] (GU - Higher school of economics, Moscow, 2011)

29. S.V. Dementieva, Bul Tomsk Polytech Univ, 308(5), 195-199 (2005)

30. S.A. Stepanov, SGZ, 2, 28-47 (2012)

31. S. Castles, H. de Haas, M.J. Miller, The Age of Migration. International Population Movements in the Modern World (Palgrave Macmillan, Basingstoke, 2014)

32. M.Y. Zelenkov, et al., Acad Strat Manag J, 20(1) (2021)

33. M.Y. Zelenkov, et al., Acad Strat Manag J, 20(5) (2021)

34. M.Y. Zelenkov, et al., Europ J Sci Theol, 17(3), 91-101 (2021)

35. V.A. Bogatyrev, P.V. Golubev, V.B. Aksinin, Sovremennye tendentsii trudovoi migratsii [Modern trends of labor migration], in Market. Entrepreneurship. Quality, 26-28 (Press, N. Novgorod, 1996)

36. N.N. Zinchenko, SGZ, 1, 138-147 (2012)

37. E.A. Ivanova, Postgrad Bul Volga Reg, 10(5-6), 139-142 (2010). https://doi.org/10.17816/2072-2354.2010.0.5-6.139-142

38. I.V. Ivakhnyuk, Employ Serv, 3, 47 (2015)

39. A.A. Nikolaev, Bul Finan Univ, 4, 90-94 (2018). https://doi.org/10.26794/2226-7867--2018-8-4-90-94 